\title{
ADVOKASI TERHADAP MASYARAKAT BOPUNCUR AKIBAT AKSELERASI PERCAMPURAN BUDAYA WISATAWAN TIMUR TENGAH DENGAN KEARIFAN LOKAL
}

\section{ADVOCACY OF BOPUNCUR CUMMUNITIES DUE TO ACCELERATION OF MIXED TOURISM CULTURE MIDDLE EAST WITH LOCAL LIFE}

\author{
M Roestamy ${ }^{1 a}$, R K Rusli ${ }^{1}$, M Aminulloh ${ }^{1}$ \\ 1Program Studi Magister Ilmu Hukum, Sekolah Pascasarjana Universitas Djuanda Bogor, \\ Jl. Tol Ciawi No.1 Kotak Pos 35 Bogor 16720 \\ a Koresponsdensi: Martin Roestamy, Email: martin.roestamy@unida.ac.id \\ (Diterima: 29-08-2019; Ditelaah: 30-08-2019; Disetujui: 08-09-2019)
}

\begin{abstract}
The development of society at this time is more advanced which involves increasingly complicated, which occurs with marriage, at this time it is spread in various media that are considered problematic in people's lives related to the term marriage contract or in the term fiqh called marriage mut'ah. Mut'ah marriage is a payment, can consist of money or goods completed with a certain period of time as well as other provisions stipulated in a particular contract or agreement, made in a marriage contract that is completed with the benefits and investment value of additional marriages. relent because in contract marriage the woman who becomes a wife also does not have inheritance rights if the husband accepts. The solutions that will be offered to be resolved prepared by partners are: 1 . Counseling to the community about understanding marriage in Indonesia; 2. Forming a community "understanding marriage law with citizens; 3. Fostering local residents in order to be able to re-socialize the understanding of the marriage law movement to the surrounding community; 4. Fostering skills in applying good understanding of marriage according to religion and according to statutory regulations in Indonesia.

Keywords: Clean water, basic needs, weak economic community.
\end{abstract}

\begin{abstract}
ABSTRAK
Perkembangan masyarakat pada saat ini semakin maju dan semakin kompleks, yang berkaitan dengan perkawinan, pada saat ini tersiar di berbagai media yaitu dengan munculnya istilah kawin kontrak atau dalam istilah fiqih disebut dengan nikah mut'ah. Nikah mut'ah adalah bayar, bisa berupa uang ataupun barang dilengkapi dengan jangka waktu tertentu serta ketentuan-ketentuan lain yang diatur dalam suatu kontrak atau kesepakatan tertentu. Hal tersebut tentunya sangat merugikan kaum perempuan dan keturunannya karena dalam kawin kontrak si wanita yang menjadi istri juga tidak mempunyai hak kewarisan jika si suami meninggal. Solusi yang akan lakukan untuk menyelesaikan masalah yang dihadapi mitra yaitu: 1. Penyuluhan kepada masyarakat mengenai pemahaman perkawinan di Indonesia; 2. Membentuk komunitas "paham hukum Perkawinan dengan warga; 3. Pembinaan warga sekitar agar dapat mensosialisasikan kembali gerakan paham hukum perkawinan kepada masyarakat sekitarnya; 4. Pembinaan keterampilan dalam penerapan pemahaman perkawinan yang baik menurut agama dan menurut peraturan perundang-undangan di Indonesia.
\end{abstract}

Kata kunci: Air bersih, kebutuhan dasar, masyarakat ekonomi lemah. 
Roestamy, M., Rusli, R. K., dan Aminulloh, M. (2019). Advokasi Terhadap Masyarakat Bopuncur Akibat Akselerasi Percampuran Budaya Wisatawan Timur Tengah Dengan Kearifan Lokal. Jurnal Qardhul Hasan; Media Pengabdian kepada Masyarakat. 5(2), 64-68.

\section{PENDAHULUAN}

Dalam Undang-undang Nomor 1 Tahun 1974 dan Peraturan Pemerintah Nomor 9 tahun 1975, pelaksanaan perkawinan merupakan momentum yang penting dan harus dilestarikan, maka selain perkawinan harus dilaksanakan sesuai dengan masingmasing agama dan kepercayaannya, perkawinan hendaklah dicatatkan, sebagaimana ditetapkan dalam pasal 2 Undang-undang Nomor 1 Tahun 1974 ayat: “ (1) Perkawinan adalah sah, apabila dilakukan menurut hukum masing-masing agamanya dan kepercayaan itu." (2) "TiapTiap perkawinan dicatat menurut perundang-undangan yang berlaku." Namun meskipun telah ada peraturan mengenai hukum dan syarat melakukan perkawinan baik secara agama maupun pemerintahan, masih saja ada individu yang melakukan perlanggaran terhadap Undang-Undang tersebut.

Pada saat ini marak di berbagai media yaitu dengan munculnya istilah kawin kontrak atau dalam istilah fiqih disebut dengan nikah mut'ah. Nikah mut'ah adalah bayar, bisa berupa uang ataupun barang dilengkapi dengan jangka waktu tertentu serta ketentuan-ketentuan lain yang diatur dalam suatu kontrak atau kesepakatan tertentu. Adanya kontrak atau kesepakatan tersebut yang menyebabkan kawin kontrak berbeda dengan perkawinan pada umumnya, karena memuat jangka waktu berakhirnya perkawinan.

Kawin kontrak dalam Islam disebut mut'ah yang secara etimologis memiliki pengertian "kenikmatan dan kesenangan", jadi tujuan dari perkawinan tersebut hanya untuk memperoleh kesenangan seksual, di lain pihak menurut syara' mut'ah adalah orang laki-laki mengawini wanita dengan imbalan harta (uang) dengan batas waktu tertentu. Dalam perkawinan mut'ah, perkawinan akan berakhir tanpa adanya perceraian dan tidak ada kewajiban bagi laki-laki untuk memberi nafkah, tempat tinggal serta kewajiban lainnya. Hal tersebut tentunya sangat merugikan kaum perempuan dan keturunannya. Karena itulah kawin kontrak tidak diperbolehkan baik menurut hukum agama maupun hukum Negara.

Pengabdian ini dilakukan di Wilayah kampung Sampay Desa Tugu Kecamatan Cisarua yang berada di Kabupaten Bogor dan berada dikawasan yang biasa disebut BOPUNCUR. Pengabdian yang akan dilakukan adalah dengan mengadvokasi masyarakat sekitar terkhusus para kaum perempuan agar pemahaman terhadap perkawinan norma dan hukum di Indonesia tidak melegalkan perkawinan semacam itu, sehingga dalam pengabdian ini difokuskan bagaimana mitra dapat menjauhi dan tidak melakukan perkawinan kontrak tersebut meskipun dalam keadaan ekonomi yang tidak dalam keadaan baik, karena hal tersebut dapat merugikan perempuan dan anak yang dilahirkannya.

\section{MATERI DAN METODE}

Metode yang digunakan yaitu dengan Focus Group Discussion (FGD) dan pendekatan partisipatif digunakan dalam kegiatan ini. Metode yang digunakan dalam kegiatan ini adalah memberikan stimulus berupa penyuluhan dengan menggunakan metode kelas atau sharing, pendampingan, instruksional, tanya jawab, diskusi, simulasi disertai praktek. Simulasi dan praktek yang dimaksud yaitu metode yang paling luas penggunaannya dalam mengevaluasi berbagai alternatif. Teknik ini mengandalkan cara (trial-and-eror) untuk mendapatkan hasil yang optimal. Teknik simulasi sebagai penyelesain masalah untuk mempelajari sistem yang kompleks yang tidak dapat dianalisis secara langsung 
dengan cara analitik. Teknik simulasi digunakan untuk memperkirakan luaran (output) dari masukan (input) sistem yang telah ditentukan.

Dalam pelaksanaan advokasi ini kepada masyarakat maka tidak dapat dilakukan secara individual melainkan harus dilaksanakan dengan bersama-sama dengan para stakeholders dikarenakan persoalan yang ada di masyarakat sudah berjalan cukup lama dan kebanyakan warga melihat bahwa hal itu sudah tidak lagi dianggap sebagai pelanggaran. Oleh karena hal tersebut langkah pertama adalah memilih beberapa orang warga yang memiliki kepeduliaan terhadap lingkungan kemudian mereka diberikan pengarahan terhadap langkah-langkah yang akan dilakukan. Setelah itu secara perlahan namun pasti memberikan kesadaran kepada warga masyarakat bahwa perkawinan kontrak dan lain sebagainya yang tidak diatur dan tidak diperbolehkan oleh perundang-undangan adalah salah.

Evaluasi pelaksanaan dilakukan dengan cara melihat apa saja yang kurang dan mesti diperbaiki, dan evaluasi ini dilihat dari banyak atau tidaknya warga masyarakat yang sadar akan hukum perkawinan yang memiliki kepeduliaan terhadap lingkungan kemudian mereka diberikan pengarahan terhadap langkah-langkah yang akan dilakukan. Setelah itu secara perlahan namun pasti memberikan kesadaran kepada warga masyarakat bahwa perkawinan kontrak dan lain sebagainya yang tidak diatur dan tidak diperbolehkan oleh perundang-undangan adalah salah.

\section{HASIL DAN PEMBAHASAN}

\section{Fenomena Turis Timur Tengah}

Kedatangan Turis Timur Tengah memiliki multiplier effect bagi masyarakat. Turis Arab tidak sekadar berwisata tetapi sudah bercampur dengan kegiatan lain dan menimbulkan pro-kontrak baik positif (kegiatan sosial, bisnis dan keagamaan) ataupun negatif.
Aroma negatif yang sudah tercium oleh pemerintah dan masyarakat yang sesekali melakukan penertiban harus terhambat oleh masalah lingkungan, masyarakat setempat atau aparat Pada umumnya berwisata secara individual tidak dengan tour leader atau group mereka tidak ingin terikat Rata-rata dalam satu bulan, masa tinggal turis diatas 10 hari. Berkembangnya wisatawan Timur tengah memberikan pengaruh terhadap sikap prilaku masyarakat BOPUNCUR baik positif maupun negatif. Kondisi ini menjadi vicé versa (saling bertentangan). Pemuka agama sudah berusaha melakukan pencegahan melebarnya dampak negatif dengan melakukan penyuluhan dan bimbingan kepada masyarakat. Namun, beberapa komunitas masyarakat yang menikmati keuntungan justru melindungi penyimpangan yang dilakukan oleh wisatawan tersebut. Peningkatan kunjungan wisatawan timur tengah secara positif telah mengundang pekerja dari luar, negatifnya adalah kedatangan pekerja sex yang melanggar budaya setempat yang religius. Namun, masyarakat melakukan pembiaran.

Perkembangan bisnis tidak mengikuti peraturan perundang-undangan mengenai investasi asing, dimana investor menggunakan nominee, dummy atau strawman yang merupakan penyelundupan hukum dan merugikan negara, investor, dan masyarakat. tetapi, terjadi pembiaran dari semua pihak yang terkait, baik masyarakat maupun aparat. (foto restoran arab sampai villa, hotel, dan toko-toko arab) .

Gambar 1. Grafik perkembangan Kunjungan Wisata.

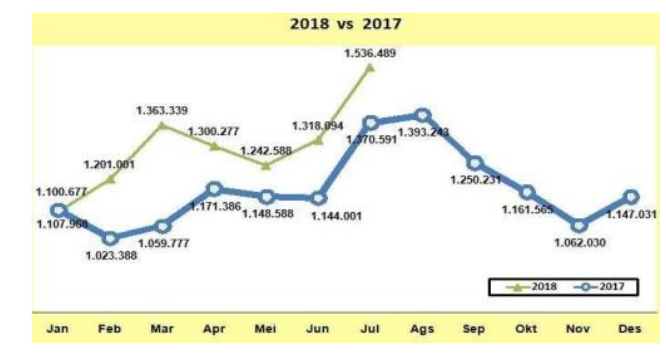

Akibat pernikahan campur (mixed marriage) dengan warganegara penganut 
ius sanguinis terjadi persoalan terhadap anak, jika terjadi perceraian, status anak sebelum berusia 18 tahun selalu menjadi sengketa yang merugikan anak.

\section{Perlindungan anak}

Negara pemerintah dan pemerintah daerah ditunjuk dan bertanggungjawab untuk memenuhi hak anak tanpa pandang etnis agama ras kelas gender kewarganegaraan budaya dan bahasa status hukum kondisi fisik dan mental, dengan ius sanguinis seorang dari perkawinan dengan laki-laki Saudi Arabia secara otomatis menjadi warga negara saudi bagaimana jika orang tuanya bercerai ketika si anak hasil pernikahan campuran belum memasuki usia 18 tahun akan selalu ada anak yang menjadi korban.

\section{Investasi Asing}

Investasi asing harus melalui perusahaan perseroan terbatas di bawah hukum Indonesia dan berdomisili di republik Indonesia investasi yang dibuat harus melalui badan keuangan dan penanaman modal jika tidak melalui lembaga ini maka dikategorikan sebagai pelanggaran hukum. Iinvestasi yang dilakukan melalui pemeran pengganti atau bayaran dapat dikategorikan sebagai penyelundupan hukum dan hal ini terjadi di banyak area wisata seperti Bali Batam dan Bopuncur.

\section{Respon Pemerintah}

Penegakan hukum belum dilakukan secara komprehensif, pemerintah cenderung melakukan pembiaran. Sementara ini pemerintah daerah khususnya sebagai penikmat dari hasil pajak atau pungutan yang dibebankan kepada masyarakat maupun wisatawan. Razia imigrasi atau kepolisian belum dilakukan secara terencana, karena penggunaan izin visa wisata banyak disalahgunakan dengan kegiatan lain. Kalaupun sesekali dilakukan inspeksi, selalu akan berhadapan dengan masyarakat yang seolah-oleh melindungi. Pengawasan akan orang asing adalah suatu keharusan, pihak imigrasi dapat bekerjasama dengan PEMDA Kab. Bogor dan
Cianjur, aparat kepolisian, maupun kementerian tenaga kerja untuk menertibkan pekerja asing.

\section{Respon Masyarakat}

Keadaan Contradictio in terminis membuat para pemuka agama dan pemimpin informal mengalami kesulitan berhadapan dengan kelompok masyarakat yang mendapat keuntungan.

\section{Gambar 2. Tempat Kawasan Bopuncur}

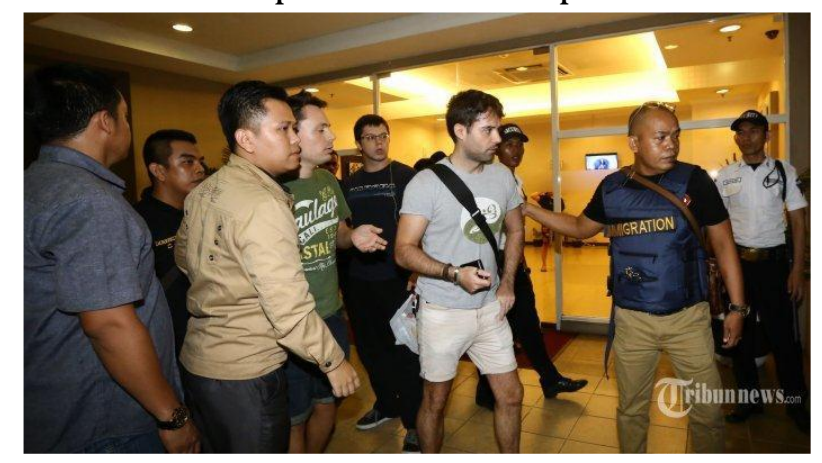

Dengan sikap penghindaran terhadap konflik, maka pengaruh negatif semakin meningkat setiap waktu dan tempat di kawasan BOPUNCUR, dan wisatawan semakin menikmati tradisi-tradisi negatif baik di daerah wisata maupun yang dibawa dari negara asalnya. Banyak wisatawan yang berprilaku menyimpang, khususnya yang tidak membawa keluarga. Sebagian masyarakat melalukan pembiaran. Peran pemuka agama dan pemimpin informal diperlukan dengan terus menerus melakukan penyuluhan, bimbingan agama, kepada masyarakat lokal untuk tidak terjerumus dari praktik penyimpangan akibat asimilasi budaya. Rasa ta'zhim masyarakat kepada habaib, berpengaruh terhadap prilaku masyarakat dalam menghadapi wisatawan timur tengah.

\section{UCAPAN TERIMA KASIH}

Ucapan terima kasih disampaikan kepada Kemristek Dikti melalui LLDIKTI Wilayah IV atas dana penelitian, kepada segenap pimpinan Universitas Djuanda Bogor atas dukungan moril dan spiritual serta fasilitas yang telah diberikan serta memberikan 
kontribusi mulai dari persiapan sampai terlaksananya kegiatan pengabdian ini. Ucapan terimakasih juga kami sampaikan kepada pimpinan Pondok Pesantren, warga masyarakat di seputaran BOPUNCUR yang telah membantu dalam pelaksanaan pengabdian ini.

\section{KESIMPULAN}

Dampak positif dari kunjungan wisatawan Timur Tengah telah dirasakan dengan perkembangan kehidupan sosial dan ekonomi komunitas BOPUNCUR, di sisi lain kedekatan komunitas dengan turis timur tengah membuka peluang untuk pelanggaran hukum dan saling melindungi. Karena percepatan asimilasi antara kedua negara telah mendorong wisatawan untuk berinvestasi seperti membangun hotel, restoran, dan ritel melalui penyelundupan legal yang melanggar ketentuan undangundang investasi. Penerimaan masyarakat secara terbuka kepada wisatawan timur tengah telah menyebabkan terjadinya pernikahan campuran, yang pada gilirannya dapat menjadikan anak-anak sebagai korban karena perbedaan dalam sistem hukum kewarganegaraan, dan konsekuensi terburuk anak-anak dapat menjadi tanpa kewarganegaraan.

\section{DAFTAR PUSTAKA}

M. Karsayuda, Perkawinan Beda Agama, Total Media, 68ogyakarta, 2006, Hlm 5

Sayyid Sabiq, Fiqih as-sunnah, Jilid VIII (Beirut: Dar al-Fikr, 1983 M-1403 H), hlm. 35

Wahjono Darmabrata, SH.MH, Hukum Perdata:Asas-asas Hukum Orang dan Keluarga, (Jakarta:Gitamajaya,2004) HIm 101

Sayyid Sabiq, Fiqih as-sunnah, Jilid VIII (Beirut: Dar al-Fikr, 1983 M-1403 H), hlm. 35

Undang-Undang

Undang-Undang Republik Indonesia Nomor 1 tahun 1974 tentang Perkawinan

Undang-Undang Republik Indonesia Nomor 12 tahun 2006 tentang Kewarganegaraan Republik Indonesia

Undang Undang Republik Indonesia Nomor 35 tahun 2014 tentang Perubahan atas Undang-Undang Nomor 23 tahun 2002 tentang Perlindungan Anak. 